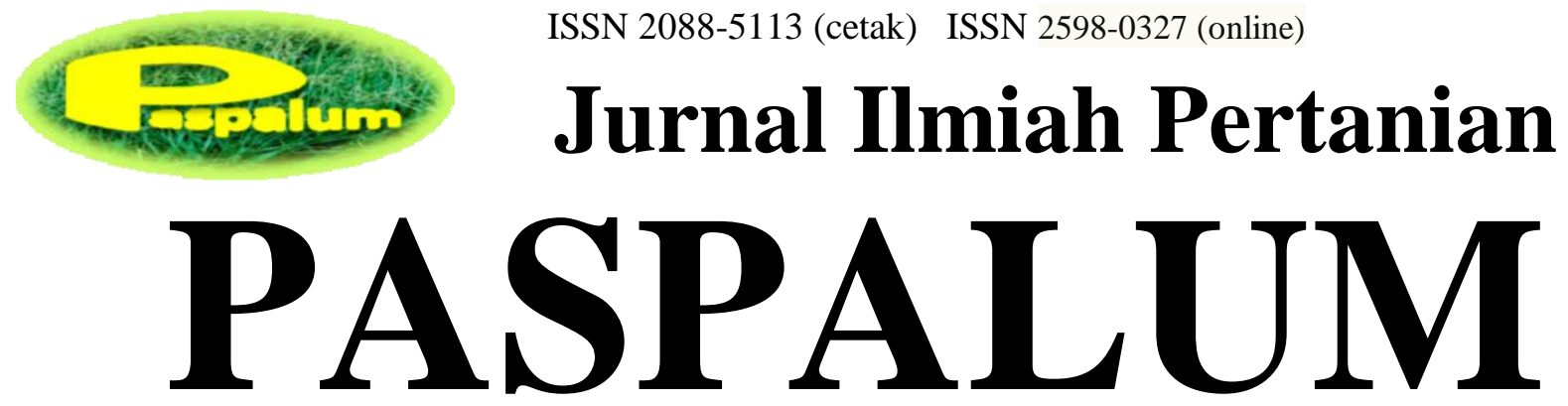

Vol. 7 No. 1 Bulan Maret Tahun 2019

http://journal.unwim.ac.id/index.php/paspalum

\title{
Pertumbuhan Beberapa Bentuk Potongan Pangkal Setek Tanaman Mawar (Rosa sp.) Akibat Cara Aplikasi Zat Pengatur Tumbuh Root-Up
}

\author{
Wendi Yuliawan \\ Fakultas Pertanian Univesitas Bandung Raya \\ wendiengkoswara@gmail.com
}

Diterima tgl 20 Januari 2019 dan disetujui untuk diterbitkan tgl 15 Maret 2019

\begin{abstract}
The research aims to study the growth of rose cuttings due to the shape of the base of cuttings and the way of Root-up application. The experiment was carried out in Screen House in Pasirbanteng, Hegarmanah Village, Jatinangor District. Sumedang Regency. The experiment was conducted from March to August 2015. The methode based on Randomized Block Design consisting of two factors. The first factor is the Root-up (W) application method which consists of 3 factor levels, namely without root up $\left(w_{1}\right)$, powder $\left(w_{2}\right)$, and paste $\left(w_{3}\right)$. The second factor is Form Cutting $(S)$ consisting of 3 levels of treatment, is the oblique sliced $\left(s_{1}\right)$, taper sliced $\left(s_{2}\right)$, and flat sliced $\left(s_{3}\right)$. The factors composed of nine combinations of treatments, each of which was repeated 3 times. The results show that was not the interaction between the shape of cuttings and Root-up applications on the growth response variables of cutting rose plants, is number of shoots, length of shoots, root length, number of roots, and root volume. The oblique sliced and tapered slice form the base and of the cutting shave the best effect on the length of shoots of rose plants cuttings
\end{abstract}

Keywords : rose plant, the shape of base cutting, root-up, growth.

\section{Abstrak}

Kajian ini bertujuan untuk mempelajari pertumbuhan setek tanaman mawar yang akibat bentuk setek dan cara aplikasi Root-up. Percobaan dilaksanakan dalam Screen House di Pasirbanteng, Desa Hegarmanah, Kecamatan Jatinangor, Kabupaten Sumedang. Percobaan dilaksanakan pada bulan Maret sampai dengan bulan Agustus 2015. Rancangan percobaan menggunakan Rancangan Acak Kelompok (RAK) pola faktorial yang terdiri dari dua faktor. Faktor pertama adalah cara aplikas Rootup (W) yang terdiri dari 3 taraf faktor, yaitu tanpa root up (w1), serbuk (w2), dan pasta (w3). Faktor kedua adalah Bentuk Setek (S) terdiri dari 3 taraf perlakuan, yaitu bentuk miring $\left(\mathrm{s}_{1}\right)$, bentuk runcing $\left(\mathrm{s}_{2}\right)$, dan bentuk datar $\left(\mathrm{s}_{3}\right)$. Dari kedua faktor tersebut tersusun 9 kombinasi perlakuan yang masingmasing diulang 3 kali. Hasil menunjukkan bahwa tidak terjadi interaksi antara bentuk setek dengan cara aplikasi Root-up terhadap variabel respon pertumbuhan setek tanaman mawar, yaitu jumlah tunas, panjang tunas, panjang akar, jumlah akar, dan volume akar. Bentuk setek miring dan setek runcing menghasilkan panjang tunas tanaman mawar yang baik.

Kata Kunci : tanaman mawar, bentuk pangkal setek, Root-up, pertumbuhan 


\section{PENDAHULUAN}

Mawar (Rosa sp.) merupakan tanaman bunga hias berupa herba dengan batang berduri. Mawar yang dikenal nama bunga ros atau "Ratu Bunga" merupakan simbol atau lambang kehidupan religi dalam peradaban manusia. Bunga mawar berkaitan erat dengan budaya di Indonesia, karena itulah tidak hanya dinikmati keindahannya saja namun merupakan bagian kebutuhan adat budaya di Indonesia (Rahmat, 1995). Bunga mawar banyak diminati konsumen karena nilai estetika yang dimiliki bernilai ekonomi cukup tinggi serta merupakan komoditas andalan dalam industri florikultura di Indonesia. Sebagai bunga potong, bunga mawar ditempatkan sebagai bunga utama.

Permintaan bunga potong mawar meningkat seiring dengan pertambahan jumlah penduduk dan perubahan gaya hidup masyarakat terutama di perkotaan. Produksi bunga mawar mengalami peningkatan sebesar 1,41 persen pada tahun 2017 dibanding dengan tahun 2016 (Suharyanto, 2018). Di pihak produsen, diinginkan waktu panen yang tepat dengan jumlah dan mutu bunga yang sesuai dengan permintaan konsumen, sehingga peningkatan permintaan bunga potong pada hari besar keagamaan dan hari-hari besar nasional dapat terpenuhi.

Untuk mendapatkan pertumbuhan dan produktivitas tanaman mawar yang baik diperlukan adanya usaha-usaha perbaikan budidaya tanaman antara lain dengan tersedianya benih yang baik secara kualitas maupun kuantitas. Pengadaan benih yang baik bisa diperoleh secara generatif maupun vegetatif tergantung tujuan yang akan dilakukan petani. Bila tujuannya untuk meningkatkan produksi bunga, maka perbanyakan secara vegetatif lebih baik, karena selain cepat hasilnya juga akan sama dengan induknya. Setek merupakan cara perbanyakan tanaman secara vegetatif buatan dengan menggunakan sebagian batang, akar, atau daun tanaman untuk ditumbuhkan menjadi tanaman baru

Wijaya and Budiana mendefinisikan setek sebagai suatu perlakuan pemisahan, pemotongan beberapa bagian tanaman (akar, batang, daun dan tunas) dengan tujuan agar bagian-bagian itu membentuk akar. Setek batang adalah salah satu cara perbanyakan sacara vegetatif yang sering dilakukan oleh petani dengan bentuk sayatan miring. Pemulihan luka pada setek dilakukan oleh sel-sel meristematik yang terbentuk antara jaringan yang tidak terluka dengan lapisan nekrotik. Lapisan nekrotik ini kemudian menghilang dan digantikan oleh kalus yang dihasilkan oleh sel-sel parenkim (Hartman et al., 1990).

Agar tanaman tumbuh sesuai harapan maka zat perangsang tumbuh atau hormon pengatur pertumbuhan terutama untuk pertumbuhan akar sudah biasa dilakukan. Auksin adalah salah satu hormon tumbuh yang tidak terlepas dari proses pertumbuhan dan perkembangan (growth and development) suatu tanaman.

Root-Up atau Rootone- $F$ adalah hormon pertumbuhan akar pada perbanyakan tanaman secara vegetatif (cangkok, setek) yang mengandung fungisida untuk mencegah infeksi dan berbagai penyakit dibagian yang terluka bekas sayatan. Cara penggunakan yang direkomendasikan ialah mencampurkan serbuk Root-Up dengan air secukupnya hingga membentuk pasta, kemudian celupkan bagian tanaman yang terluka sayatan (setek). Rootone- $F$ diformulasikan oleh Agrocarb adalah zat pengatur tumbuh sintetik berupa serbuk warna putih yang mengandung 1naftalenasetamida (NAA) $0.2 \%, 2$-metil-1naftalen asetat (MNAA) $0.03 \%$, indol-3butirat $0.06 \%$, bahan aktif tersebut termasuk golongan auksin, sedangkan tetrametilthiuram disulfide (Thiram) $4.00 \%$ berfungsi sebagai fungisida (Sudrajat and Wahyono, 2002). 
Mekanisme kerja Auksin adalah mempengaruhi pemanjangan sel-sel tanaman, Auksin menginisiasi pemanjangan sel dengan cara mempengaruhi pelenturan dinding sel. Auksin memacu protein tertentu yang ada di membran plasma sel tumbuhan untuk memompa ion $\mathrm{H}^{+}$ke dinding sel. Ion $\mathrm{H}^{+}$ini mengaktifkan enzim tertentu sehingga memutuskan beberapa ikatan silang hidrogen rantai molekul selulosa penyusun dinding sel. Sel tumbuhan kemudian memanjang akibat air yang masuk secara osmosis. Setelah pemanjangan ini, sel terus tumbuh dengan mensintesis kembali material dinding sel dan sitoplasma. Zat pengarur tumbuh Auksin yang digunakan adalah Natrium NAA (naphthyl acetic acid / asam naftali asetat (Kusumo, 1990).

Selama proses yang dilakukan dalam perbanyakan tanaman mawar. penggunaan zat pengatur tumbuh dari auksin sangatlah penting, karena dapat membantu mempercepat proses pertumbuhan akar. Namun penggunaan zat pengatur tumbuh bila digunakan dengan konsentrasi rendah akan merangsang dan menggiatkan pertumbuhan tanaman, dan sebaliknya bila digunakan dalam jumlah besar atau konsentrasi tinggi akan menghambat pertumbuhan bahkan dapat mematikan tanaman (Abidin, 1983). Rootone $F$ merupakan zat pengatur tumbuh yang memacu terbentunya akar pada setek dan paling cepat membentuk akar 25 hst (hari setelah tanam) dengan persentase setek yang tumbuh $66.70 \%$ (Hartutiningsih et al., 2005).

\section{METODOLOGI}

Metode penelitian mempergunakan pendekatan eksperimen yang dilaksanakan di dalam screen horse, bertempat di Pasirbanteng Desa Hegarmanah Kecamatan Jatinangor Kabupaten Sumedang, berada pada ketinggian 800 meter dari atas permukaan laut, dengan rata-rata curah hujan $1.600 \mathrm{~mm} /$ tahun, temperatur berkisar antara $16^{\circ} \mathrm{C}$ sampai dengan $28^{\circ}$. Percobaan dilaksanakan pada bulan Maret sampai dengan bulan Agustus 2015.

Bahan yang akan dipergunakan selama percobaan adalah setek batang dari jenis mawar fortuna, ZPT Root-Up, media tanam berupa sekam bakar, pupuk kandang, dan pestisida. Alat yang digunakan adalah timbangan halus, oven, setek bak, gunting setek, sungkup, handspayer dan kelengkapan lain berupa alat untuk mengukur suhu udara, dan kelembaban udara (hygrotermometer).

Rancangan percobaan yang digunakan adalah Rancangan Acak Kelompok (RAK) pola faktorial yang terdiri dari dua faktor. Faktor pertama adalah Cara Aplikasi Root-Up (W) terdiri dari 3 taraf $\left(\mathrm{w}_{0}=\right.$ Tanpa Root-Up, $\mathrm{w}_{1}=$ Serbuk, dan $\mathrm{w}_{2}=$ Pasta) dan faktor kedua adalah Bentuk Setek (S) terdiri dari 3 tarap perlakuan $\left(\mathrm{s}_{1}=\right.$ Setek miring, $\mathrm{s}_{2}=$ Setek runcing, $\mathrm{s}_{3}=$ Setek datar )percobaan diulang 3 kali. Variabel respons yang diamati yaitu: Jumlah Tunas, Panjang Tunas, Jumlah akar, Panjang Akar, Volume akar pada umur 85 HST.

\section{HASIL DAN PEMBAHASAN}

Indikator keberhasilan stek adalah terbentuknya akar adventif. Pembentukan akar adventif terdiri dari beberapa tahap, yaitu inisiasi sel-sel meristematik, diferensiasi selsel meristematik tersebut menjadi akar primordia, serta pertumbuhan dan perkembangan akar baru. Seringkali munculnya akar didahului oleh pembentukan kalus, akan tetapi adanya kalus tak merupakan tanda bahwa setek dapat menghasilkan akar. Kalus adalah kumpulan sel parenkim yang bentuknya tidak beraturan dalam tahap lignifikasi yang bervariasi. Pembentukan kalus dan pembentukan akar tersendiri satu dengan lain, meskipun keduanya berhubungan dengan pembelahan sel (Hartman et al., 1990). Pada percobaan ini, semua perlakuan pada stek batang tanaman mawar berhasil membentuk akar adventif. 
Perkembangan akar dan tunas setek dipengaruhi oleh kandungan bahan setek. Terutama persediaan karbohidrat dan nitrogen. Hartmann dan Kester (1978) menyatakan bahwa setek yang mengandung karbohidrat tinggi dan nitrogen yang cukup akan membentuk akar dan tunas. Pada kondisi lingkungan tumbuh yang sesuai, setek batang lebih mudah membentuk bagian-bagian vegetatif yang lain dan tumbuh menjadi individu yang sempurna (Hartman and Kester, 1978).

Auksin adalah satu-satunya kelas hormon tumbuhan yang mempengaruhi pengakaran dan digunakan secara komersial untuk menstimulasi pengakaran adventif (Arteca, 2006). Zong et al. (2008) menambahkan bahwa peran utama auksin pada perbanyakan tanaman adalah menstimulasi akar pada setek batang dan daun dan meningkatkan cabang akar. Kegunaan dari hormon yaitu secara keseluruhan meningkatkan persentase pengakaran, mempercepat inisiasi pengakaran, meningkatkan jumlah dan kualitas dari akar, dan mendorong pengakaran yang seragam (Panjaitan et al., 2014; Sulasiah et al., 2015).
Akan tetapi dalam percobaan ini peranan auksin tidak terlihat pengaruhnya.

Hasil analisis statistik menunjukkan tidak terjadi interaksi antara zat pengatur tumbuh dengan bentuk stek terhadap semua variabel yang diamat; hasil analisis efek mandiri dengan Uji Jarak Berganda Duncan pada taraf $5 \%$ untuk masing-masing variable pengamatan disajikan pada Tabel 1. Cara pemberian zat pengatur tumbuh Root up tidak terdapat perbedaan pengaruh yang nyata terhadap jumlah tunas, panjang tunas, jumlah akar, panjang akar, dan volume akar setek batang tanaman mawar. Hal ini diduga disebabkan oleh Auksin endogen yang yang terdapat pada tanaman tersebut yang sudah mencukupi sehingga pemberian Auksin eksogen tidak akan memberikan pengaruh dalam permbentukan akar. Hal ini menujukkan bahwa jika di dalam bahan stek sudah cukup terdapat ZPT endogen, maka penambahan ZPT eksogen tidak diperlukan. Sebaliknya, jika bahan stek berada dalam kondisi kurang ZPT endogen, maka keberhasilan penyetekan sangat ditentukan oleh penambahan ZPT eksogen (Apriliani et al., 2015; Sulasiah et al., 2015).

Tabel 1. Jumlah Tunas, Panjang Tunas, Jumlah Akar, Panjang Akar, dan Volume Akar Stek Mawar akibat Zat Pengatur Tumbuh Root Up dan Bentuk pangkal stek Umur 85 HST

\begin{tabular}{cccccc}
\hline \multirow{2}{*}{ Perlakuan } & \multicolumn{5}{c}{ Rata-rata } \\
\cline { 2 - 6 } & Jumlah Tunas & Panjang Tunas & Jumlah Akar \\
....tunas & ..cm... & Panjang Akar & Volume Akar \\
..cm.. & ..ml.. \\
\hline ZPT Root up & $2.30 \mathrm{a}$ & $10.43 \mathrm{a}$ & $13.85 \mathrm{a}$ & $14.04 \mathrm{a}$ & $0.72 \mathrm{a}$ \\
$\mathrm{w}_{0}$ & $2.07 \mathrm{a}$ & $12.78 \mathrm{a}$ & $11.93 \mathrm{a}$ & $15.11 \mathrm{a}$ & $0.78 \mathrm{a}$ \\
$\mathrm{w}_{1}$ & $2.07 \mathrm{a}$ & $12.97 \mathrm{a}$ & $12.26 \mathrm{a}$ & $14.00 \mathrm{a}$ & $0.84 \mathrm{a}$ \\
$\mathrm{w}_{2}$ & & & & & \\
Bentuk setek & $2.22 \mathrm{a}$ & $11.99 \mathrm{~b}$ & $13.63 \mathrm{a}$ & $14.96 \mathrm{a}$ & $0.83 \mathrm{a}$ \\
$\mathrm{s}_{1}$ & $1.96 \mathrm{a}$ & $13.38 \mathrm{~b}$ & $12.00 \mathrm{a}$ & $12.89 \mathrm{a}$ & $0.80 \mathrm{a}$ \\
$\mathrm{s}_{2}$ & $2.33 \mathrm{a}$ & $9.54 \mathrm{a}$ & $12.37 \mathrm{a}$ & $13.74 \mathrm{a}$ & $0.83 \mathrm{a}$ \\
$\mathrm{s}_{3}$ & & & & & \\
\hline
\end{tabular}

Keterangan : Nilai rata-rata yang ditandai dengan huruf yang sama pada kolom yang sama berarti berbeda tidak nyata menurut uji Jarak berganda Duncan taraf nyata $5 \%$ 
Bentuk potongan setek hanya bepengaruh nyata tehadap panjang tunas, sedangkan pengaruhnya terhadap variabel yang lain tidak berbeda. Bentuk potongan bagian pangkal setek lebih baik dibuat miring. Hal ini disebabkan akan diperoleh permukaan pangkal setek yang luas sehingga jumlah akar yang tumbuh akan lebih banyak. Selain itu akan dihasilkan satu akar yang besar di ujung irisan karena di tempat itu terjadi akumulasi zat tumbuh (Wijaya and Budiana, 2014). Sejalan dengan hasil penelitian Yunianto (2014), bentuk potongan pangkal runcing memiliki pengaruh yang terbaik terhadap pertumbuhan stek buah naga.

\section{KESIMPULAN}

Hasil penelitian menunjukkan tidak terjadi interaksi antara cara aplikasi Root-up dengan bentuk setek terhadap variabel jumlah tunas, panjang tunas, panjang akar, jumlah akar, dan volume akar setek batang tanaman mawar. Cara aplikasi Root-up tidak berbeda pengaruhnya tehadap semua variabel yang diamati, sedangkan bentuk potongan setek berpengaruh nyata tehadap panjang tunas. Tidak terdapat cara aplikasi Root-up yang berpengaruh baik terhadap pertumbuhan setek tanaman mawar. Bentuk potongan setek miring dan bentuk meruncing menghasilkan panjang tunas yang baik.

Saran yang dianjurkan untuk menggunakan dosis aplikasi root-up yang berbeda sehingga diperoleh perbandingan hasil apakah semakin besar dosis akan memberikan hasil yang efektif atau sebaliknya.

\section{DAFTAR PUSTAKA}

Abidin, Z. 1983. Dasar-dasar pengetahuan tentang zat pengatur tumbuh : auxin, gibberelin, cytokinin ethylene, inhibitors. Angkasa, Bandung.

Apriliani, A., Z. Aneloi, and Suwirmen. 2015. Pemberian Beberapa Jenis Dan
Konsentrasi Auksin Untuk Menginduksi

Perakaran Pada Stek Pucuk Bayur

(Pterospermum javanicum Jungh.)

Dalam Upaya Perbanyakan Tanaman

Revegetasi. J. Biol. Univ. Andalas 4(3):

178-187.

http://jbioua.fmipa.unand.ac.id/index.php /jbioua/article/viewFile/166/158.

Arteca, R.N. 2006. Introduction to Horticultural Science. Thompson Delmar Learning, a part of the Thomson corporation, New York.

Hartman, H.T., and D.E. Kester. 1978. Plant Propagation Principle and Practise. 2nd ed. Pentice Hall, Inc. Englewood, New Jersey.

Hartman, H.T., D.E. Kester, and F.T. Davies Jr. 1990. Plant propagation, princples and pracies. 5th ed. Prentice Hall, Inc. Engle Wood Cliff, New Jersey.

Hartutiningsih, I.P. Suendra., and M. Siregar. 2005. Mawar Hijau (Rosa x odorata "viridiflora") di Kebun Raya Bali :

Biologi Perbungaan dan

Perbanyakannya. Biodiversitas 6(3): 181-184.

Kusumo, S. 1990. Zat Pengatur Tumbuh. Yasaguna, Jakarta.

Panjaitan, L.R.H., J. Ginting, and Haryati. 2014. Respons Pertumbuhan Berbagai Ukuran Diameter Batang Stek Bugenvil

(Bougainvillea spectabilisWilld.)

Terhadap Pemberian Zat Pengatur Tumbuh. J. Online Agroekoteknologi 2(4): 1384-1390.

https://media.neliti.com/media/publicatio ns/101393-ID-respons-pertumbuhanberbagai-ukuran-diam.pdf.

Rahmat, R. 1995. Mawar, Seri Bunga Potong. Kanisius, Yogyakarta.

Sudrajat, H., and S. Wahyono. 2002. Pengaruh Rootone F terhadap stek Batang Poko (Mentha arvensa L.). p. 328-334. In Simposium Nasional II Tumbuhan Obat dan Aromatik. Bogor.

Suharyanto. 2018. Statistik Tanaman Hias Indonesia. Badan Pusat Statistik/BPSIndonesia, Jakarta.

Sulasiah, A., C. Tumisilar, and T. Lestari. 2015. Pengaruh Pemberian Jenis Dan Konsentrasi Auksin Terhadap Induksi Perakaran Pada Tunas Dendrobium sp SECARA In Vitro. Bioma 11(1): 56-66. 
47|Paspalum: Jurnal Ilmiah Pertanian Volume 7 No 1 Maret 2019

Wijaya, and N.S. Budiana. 2014. Membuat

Setek, Cangkok, Sambung dan Okulasi.

Penebar Swadaya, Jakarta.

Yunianto, T.. 2014. Pengaruh Pemberian

Rootone-F dan Bentuk Potongan Pangkal

Terhadap Pertumbuhan Stek Buah Naga.

Zong, M.C., Z. Yi Li, and Zhen. 2008. Plant

Growth Regulators Used in Propagation.

Plant Propagation, Concepts and

Laboratory Exercices. CRC Press. 